\title{
THE EFFECTS OF SOUND STIMULATION ON HISTOPATHOLOGICAL CHANGES OF CORTI'S ORGAN WITH SPECIAL REFERENCE TO ITS DISTRIBUTION
}

\author{
By \\ K. KIKUCHI \\ From the Department of Oto-Laryngology, School of Medicine. Nihon University \\ (Director: Prof. S. Nakanura)
}

This paper reports influence of pure tone stimulation on histopathological changes of Corti's organ of normal guinea pig. The sound stimulations were conducted through metal tube directly from 1000 , $200 \mathrm{~J}$ and $4000 \mathrm{cps}$ pure tone souce to ear drum of guinea pig, and the sonnd level just before the ear drum was settled between 100 and $135 \mathrm{db}$. The results obtained were as follows

1. On the $1000 \mathrm{cps}$ stimulation group, critical intensity line was determined, which was connected with the intensity and duration of sound stimulation and was able to separate the reversible and irreversible change of Corti's organ,

2. On the $1000 \mathrm{cps}$ stimulation group, the begining of the most demaged region was observed between 10.0 and $10.6 \mathrm{~mm}$ from basal end.

3. On the 1000 cps stimulation group, when the sound level was intensified, the demaged region was extended little to helicotrema but chiefly to basal end and the center of the demaged region was observed between 8.0 and $9.4 \mathrm{~mm}$ from basal end.

4. On the $2000 \mathrm{cps}$ stimulation group, the center of demaged region was observed between 7.0 and $7.8 \mathrm{~mm}$ from basal end and was near to basal end compared with that was on the $1000 \mathrm{cps}$ stimulation group.

5. On the $4000 \mathrm{cps}$ stimulation group, the center of demaged region was near to basal end compared with that was on $2000 \mathrm{cps}$ stimulation group, and observed between 6.4 and $7.2 \mathrm{~mm}$ from basal end.

\section{純音刺激と聴器病変; 特に Corti’s organ の病変の$$
\text { 拡がりかたについて }
$$

日本大学医学部耳鼻咽㗹科学教室（主任：中村四郎教授）

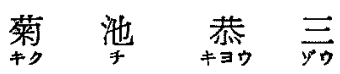

\section{I. 緒}

\section{言}

音響性外傷に関する実験的牙究の歴串は古く，既に 20 料紀の初頭にその端を発して，今日に至るまでいぜんと してあらゆる看度からその湌索が行われている。その 間，時代の変䙴上共に研究方法にるいらいろと改良と工 夫が加えられてきている，殊に最近急激に発涬した電気 音響学の新しい技術の導入のもとに, audiology の飛躍

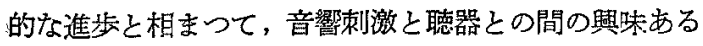
相関關が，従来の研究方法をむつてするよりる，より
一㿿の精密さをもつて研究され，乙たがつて，あるもの では，従来の成績とは異つた形に乩いてその成果がえら れてきた。近代の機械文化の躍進的な発達に伴つて，本 研究の重要性はますます高く，乙か子多售的な研究分野 の発屡が強く望ま机ているよらに思われる。

電気音響学的基礎のもとに行つた音響性外傷に関して は，米国に拈いて Perlman (1941) 1) が豊富な臨床例 と实験的研究を坏告し，Lurie (1944) ら2)は強大な純 音を長時間曝露した場合の Corti's organ $の$ 解剖学的 
損傷を組織学的に観察し，Bèkésy (1949) 3) は基底膜の 振動から伝音の理論を考究し, Davis (1953) ら4)は, 独自の腐究方法によつて動物実験を行い, cochlear microphonics と組織学的所見との相互関係を何;究した。

また，欧州に执いては，Rüedi and Furrer (1954)Б) が人間と動物について実験を重ね，欧米グルーブの石究 を比較して夫々の成績が一致したことを立証した。

その他, 臨床的䂙究についてはきわめて多数の業績が 発表されている。

一方, 本邦に拈いては, 占くは Siebenmann 門下の 吉井 (1909) 6) を始め，すぐれた数多くの矿究があげら れるが，強大な音響環境が次第に社会問題となりつつあ る今日, 基礎的方究の一つとして純音刺晖による聴器の 障害の度合いを検索して, その病变の可 逆性の問題を追求することは甚だ重要な 矿究課題であると思われる，殊に音響 刺激により，その聴閾值の最大上昇値 が刺激音よりも 1 octave 上位に現われ る場合を acoustic trauma と定義する (Zwislocki, 1949) 7) ならば, acoustic trauma の概念もその範囲がきわめて広 く, 夫々の場合の Corti's organ にお ける病変も可逆性から不可逆性へときわ めてさまざまであることが予想され, 従つて, その可逆 性の限界点の分布が，刺激強度と刺激時間との関連に市 いて, 拈よそどのへんに求められるかということを検索 することは，臨床的にも甚だ與味のあること〉思われる ので本矿究を行つた．またこの問題に関連して, cochlear frequency localization の検討も意義あること〉思 われるので graphic cochlear reconstruction 法をとり 入れて実験結果をこれまでのものよりもより詳細に観察 を行つたのでこつに報告する。

\section{II. 研究方法}

\section{A. 実験動物}

体重 300〜400gr. の健康なモルモットを使用した。 雌雄の別や毛並は一定しなかつたが，外耳道和よび鼓膜 に著変なく,かつ Preyer 氏反応良好なものを選んで 実験に供した。

\section{B. 純音刺激装置}

純音刺激装置と乙ては, 純音発振器, 増幅器および driver unit を用いた. 純音発振器としては菊水電波製 R-C Signal Generator ORC-27 を，増幅には山水電
機製 Amp Model Q-50 をそそして driver unit とし てはブシダ音響製 RU-15, RU-20, RU-25 および特製 の RU-25を用いた。

純音をモルモットの豉膜に直接導くためには，直径 $1.5 \mathrm{~cm}$, 長さ $28 \mathrm{~cm}$ の金属性 tube の一端を driver unit に接続し，他端に耳鏡を装脂し，この耳鏡をモルモット の外耳道に插入密着した. その block diagram は第》 図の通りである。

第 1 図純音刺激装置

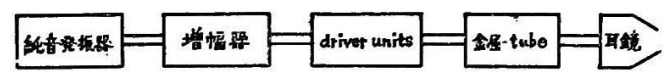

純音発振器より生じた純音を增幅してその sine wave の波形に歪のないことを確めた（第 2 図）.

第 2 図 実験に用いた sound system の波形

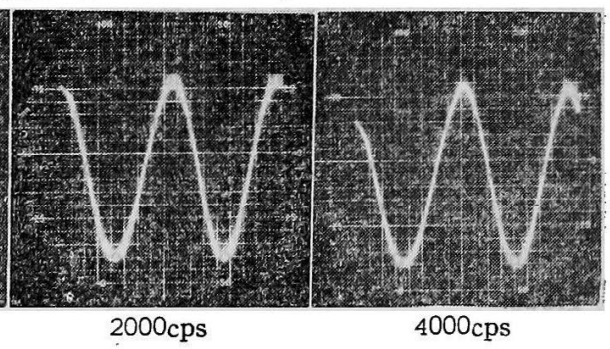

C. 音圧測定装置

従来の音圧測定法は, Davis et al (1953) 4) を绦き, その殆んどすべてのものが指示騒音計によるものであつ たが，本研究に批いては, probe-tube microphone (東 京理工矿究所製)を使用して，鼓膜に接した音圧を則定 した. Microphone は定期的に輐正されたが，音圧測定 装置㧍よび mic. の較正装置の block diagram は第る 図に示した。

第 3 図音圧测定装置打よび mic. 較正装置

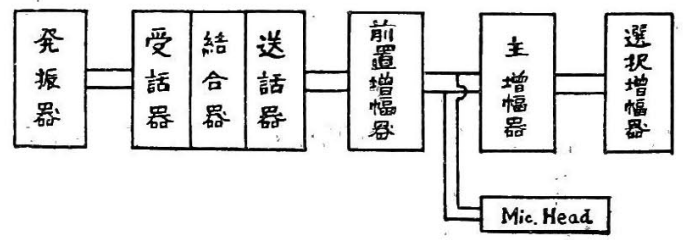

本装置の microphone head $に$ probe-tube を装置 ることにより, 鼓膜直前, すなわら前方約 $2 \mathrm{~mm}$ の音圧 が正確に測定された. Probe-tube の插入法は第 4 図に 示されるが，実験に当つては音響が鼓膜に向つて正しく 導入されるよう特に留意した。 
第 4 図耳鏡と microphone head と probe tube との位置的関倸

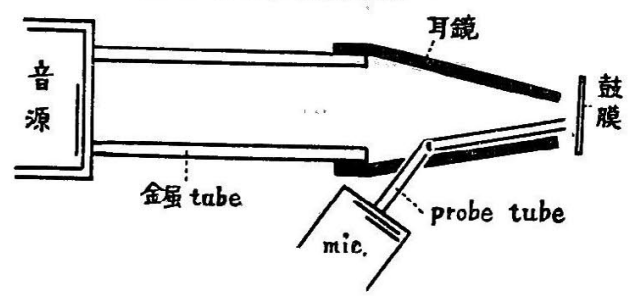

D. 音幛刺激法

モルモットの腹腔内に 20\% urethane 1.5〜2.0cc を 注射して全身麻酔を施し，身体の運動を制限した後，背 臥位とし，上下肢と頭部とを固定し，音響装㯰より発す る音響を tube を介して外耳道より敨膜に直接導いた。

刺激音の振動数としては, 1000, 2000 および 4000cps の各周波数を選び，音圧は 135〜100db（re. 0.0002 microbar) 音響曝露時間は 2〜60 分 $(2,3,5,6,10$, $12,13,15,17,20,25,30$ \& 60 分）とした。

第 5 図 Corti's organ 損傷の度合と分布図
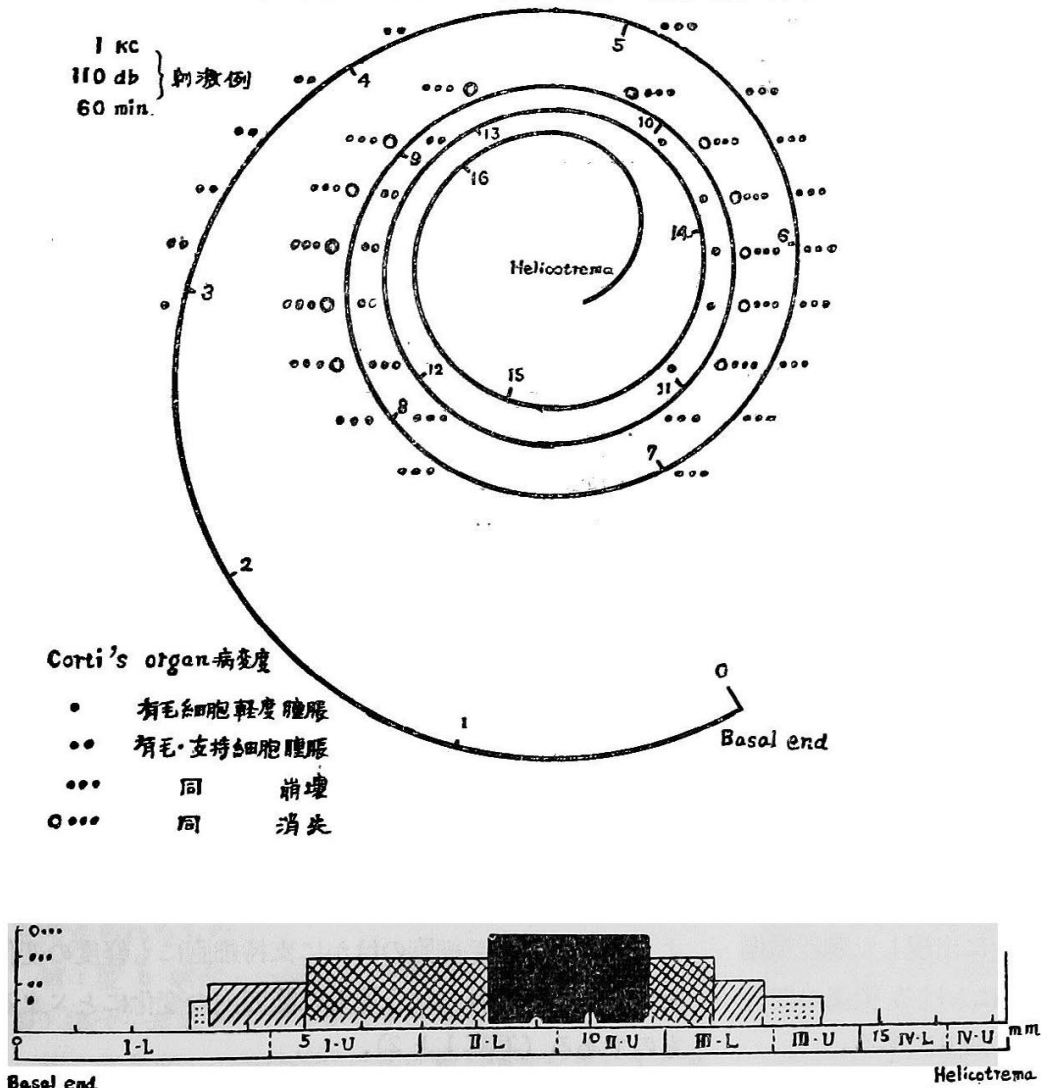

これらの音謷負荷実験は，すべて防音箱内に始いて行 われたが，この箱全体は脚によりコンクリート床上約 $80 \mathrm{~cm}$ に浮き亡らせ, 実験室の壁拈よび床などからの振 動の伝播を極力防ぐように留意した．防音箱は容積約 $60 \times 80 \times 12.0 \mathrm{~cm}$ であり，その壁はすべて 外面より数党 て，厚い木板，ロックシール，テックス，鉄板、テッッ ス，ロックッール，木板，吸音材（但し底面のみ硝子） の各贋より構成さされている。

\section{E. 組織学的検查:}

音響を一定時間負荷された後，モルモットは生体固定 に移された。すなわら, 法に従つてモルモットの循環系 を生理的食塩水で灌流した後，Wittmaack-山川氏液 学注入し牛体固定した後, 側頭骨をとり出し左右の聴器 を摘出した。この骨標本は，更に5\%硝酸液で脱灰し， alcohol にて脱水後, celloidin 包埋を行い, 蝸牛軸 に平行に こ0micron の連続切片とし, HematoxylinEosin 重染色を行い，必要に応じて PAS 染色をもあ ふせ行い鏡検した。

一方，これらの連䋨切片標 本を基礎として, 教室の堀川 9) にならつて, graphic: cochlear reconstruction を行つ て傷害部位を詳細に測定し， これと同時に reconstruction より泪定された basilar membrane を一直線上に引き延 ばして, 傷害部位の観察を容 易にした(第 5, 6,7 図参照).

III. 実験成綘

咅響刺激による障器障害を 推察するにあたり，その病変 の度合いに影響を与える重大 な因子は，与えられた音圧と 懪露時間および刺激音の振動 数であるとは内外の研究者の 一致した見解である・そこで 本実験に执いては，刺激音の 振動数としては，1000，2000 扣よび 4000 cps を用い, 刺 激音圧は最高 $135 \mathrm{db}$ から 100 $\mathrm{db}$ まで $5 \mathrm{db}$ step で段階を とり, 又曝露時間は 2 分から 
60 分迄の間として，これら 両者を適当に組み合わせた．

A. 剖検所見

音圧および暴露時間の夫々 の增加にほよ゙比例して，中耳 腔内壁面, cochlea 表面, 又 は鼓膜に出血点ないし出血斑 が認められた.すなわち，音 圧 $135 \mathrm{db}$ では曝露時間 5 分 より中耳腔内壁面など所々に 茶褐色を帯び切め，8 分上り 鼓膜にも出血点が認められ， 10分以上では明らかに出血斑 が現われていた。

しかし，鼓膜破裂は，全例 そおいて認められなかつた。

B. 組織学的所見

標本を観察するに当つては， すべて graphic cochlear reconstruction を行い, 有毛細 胞については, 胞体の膨化， 胞体構造の不明確化, 空胞形 成, 支持細胞よりの剥離, 榕 の位置異常, chromatin の分 布異常, pyknosis の有無な ぞに関してしらべ, 支持組織
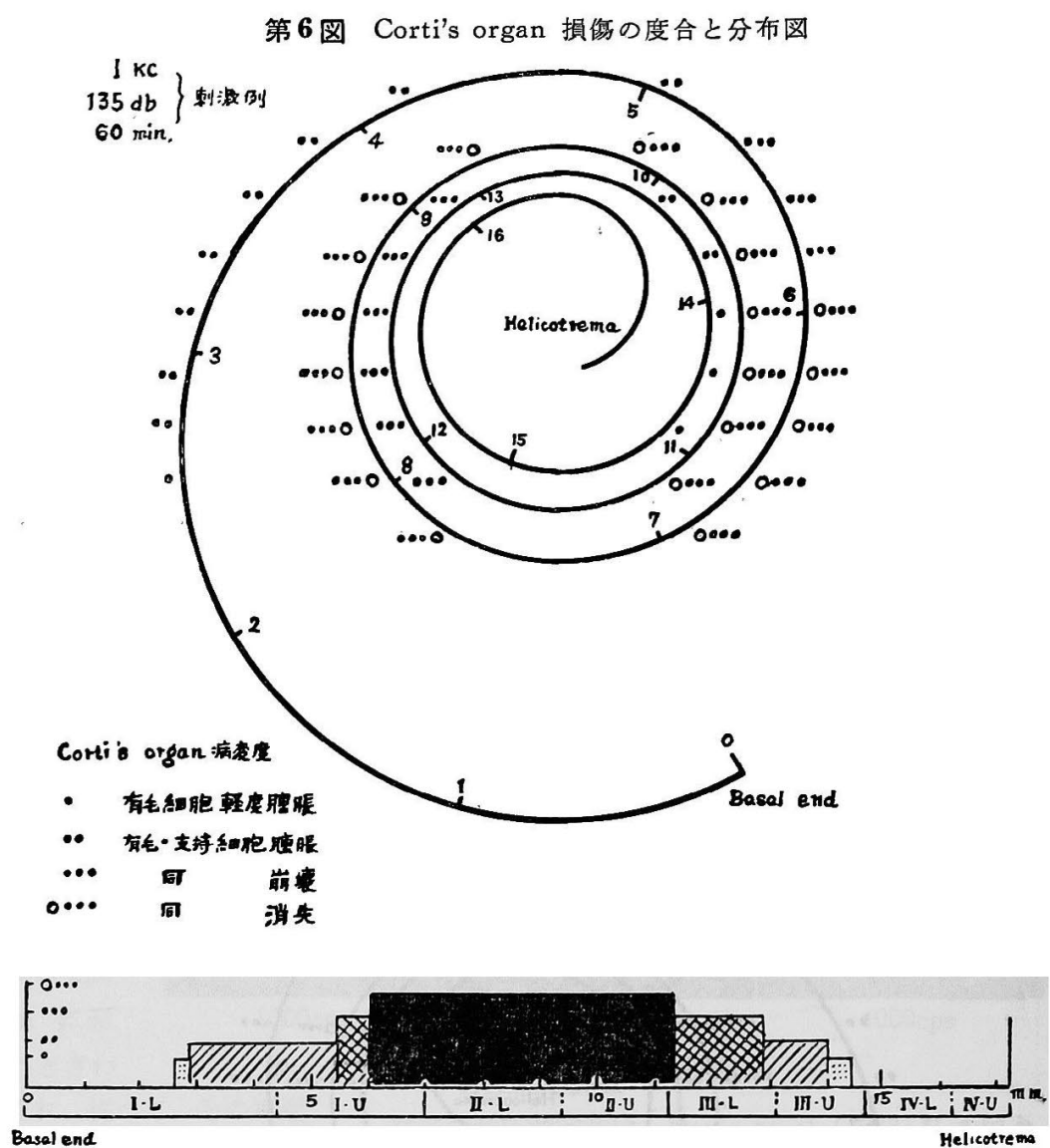
そついては，Deiter 氏細胞, Hensen 氏細胞, Claudius 氏細胞の夫々について，胞体の形態と基底膜よりの剝離 扣よび核の状態などについて観察し，又，被蓋膜，Reissner 氏膜の形態, mesothelial cells の配列巽常などを み, 又蝸牛殼管, 前庭階, 鼓室階あるいは血管带附近の 出血の有無, シセン神経節細胞の变化などについてしら べた. Tunnel 腔や Nuel 腔内に現われる hyalin よ う物質は病的とみなしたが，有毛細胞間に稀に現われる 不明の exudate ようのむのを認めることがあつたが，

これは対照実験にも現われることがあるのでこれは病的 とみなさなかつた．これは恐らく標本作製途中でおこる ものかもしれない (Werner) ${ }^{10)}$.

実験成績を述べる前に，本府;究中に出現した聴器損傷 の一般所見および Corti's organ Kおける 損傷の度合 いの分類法について説明すれば次の通りである.

Corti's organ の損傷に対する 租䋨学的分類 294) i)
については, こつでは組織学的所見と聴器の有する機能 の点からみて, 病変を次の 3 度に分類した.

組織学的には:

第 1 度病変……有毛細胞は腫脹軽度で, 細胞壁は比較 的原形を保ら，䄱の変位，pyknosis を認める。支持租 織, 殊に Deiter 氏細胞や Hensen 氏細胞の腫脹は軽度 で，基底膜よりの剝離は認められない．Mesothelial 又はきわめて軽微であるもの.

この第 1 度の変化を更に $\mathrm{a}, \mathrm{b}$ の 2 群に分けたが，こ のうち a は Corti's organ の所見が正常か, 又は外有 毛細胞の軽度嗹脹, 核の变位, あるいは軽度の pyknosis を示すものまでのものであり, b は細胞の変化が a よりも強く, 有毛細胞の庄かに支持細胞にも軽度の変化 を示したが，それらは上述した範囲内の変化にとら゙まる ものである. (写真 1 と2).

第 2 度病変……有毛細胞や支持組織の䏦涱強く, 基底 cells の性状の変化, 又はその減少は認められないか, 
第7図 Corti's organ 損伤の度合と分布国

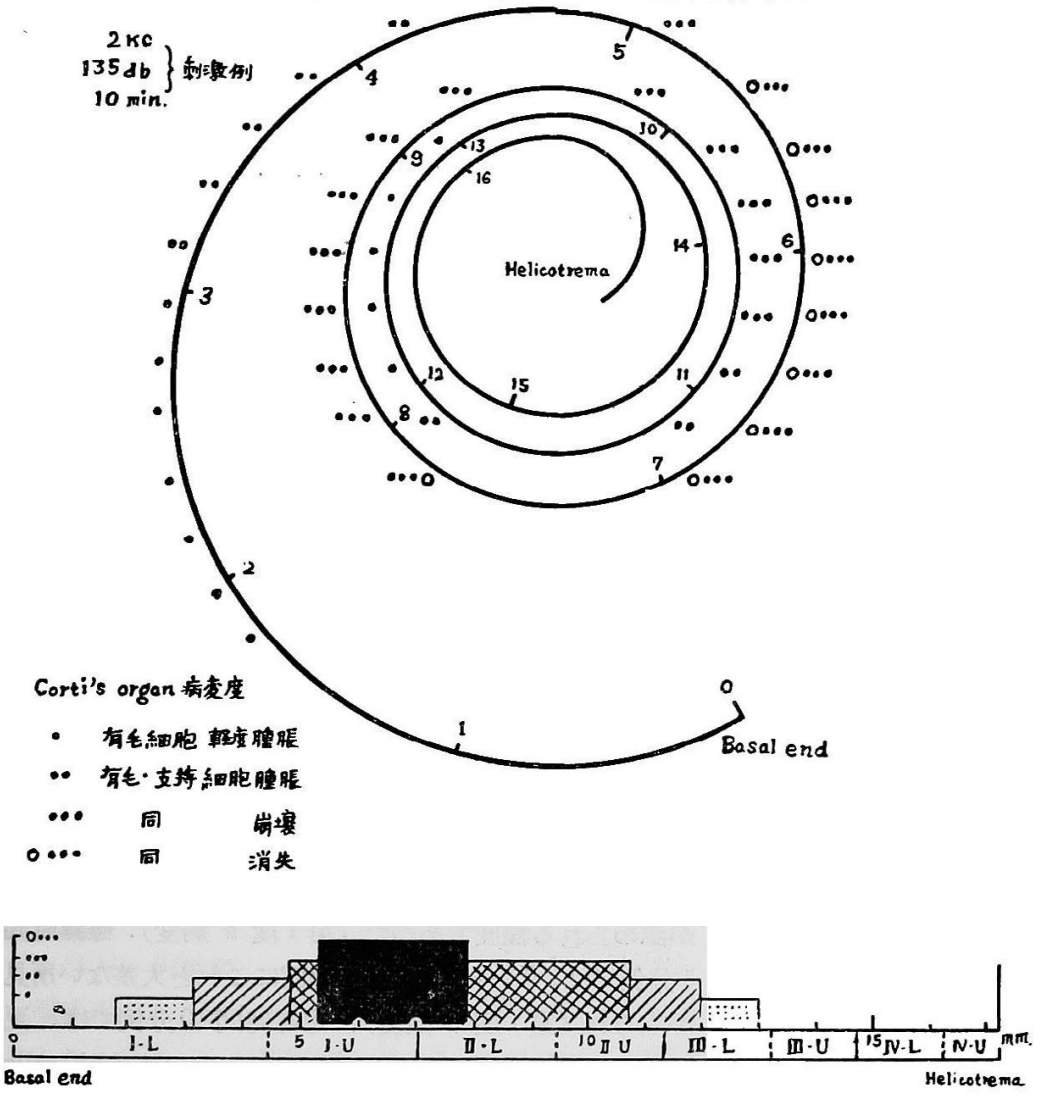

第 3 度病変.......進行性の 永久聴ナ損失をきたして病 変は完全に不可逆性である と考穴られるもの.

標本は，すべてこの分類 法に従つて観察されたが, 特に内外有毛細胞, 支持細 胞, mesothelial cells の 変化を主として検索した. 以下文中にある（）内 は損傷の程度を示す

C. $1000 \mathrm{cps}$ 刺激群 (第 1 表)

本実験啫:では，刺激音圧 100〜135db にわたる各種 条件により，てルモット37 匹に試みたが，標本完成に いたるまでの失敗例が 5 例 あつたために，これらを除 外して総数 32 例について, その成績を述べる。

$100 \mathrm{db}$ 刺激群

懪露時間 12 分例では， 有毛細胞の 損傷は, basal end より $5.4 \sim 12.5 \mathrm{~mm}$ の 範囲に認められた．この範
膜よりの剝離が軽度で mesothelial cells の減少をみる むの (写真 3 ).

第 3 度病変......有毛細胞や支持細胞の崩壊強く, 明ら かに基底膜より剥離する．また mesothelial cells の消 失が認められる（写真 4 と 5).

さらに Corti's organ 全体が消失する場合もみられ る (写真 12).

以上の 3 段階の病変に分類したが，これらの変! 器の有する機能の点からみて, 夫々つぎの遥程に対応す るものとの推察の下に分類を試みた次第である。

第 1 度 a 病変......殆んど正常の聴力を保持しうるか， 又は病変が回復して殆んど正常の聴力にまで回復しうる と考えられるもの。

第 1 度 $\mathrm{b}$ 病変......病変が回復に向つても正常にまで 復し得ず一部に聴力損失を残すと考えられるもの.

第 2 度病変......部分的には永久聴力損失をきたすと考 えられるもの.
囲では，有毛細胞については，胞体の構造は明確である が，核に軽度の pyknosis が認められるのみで, 空胞形 成や支持細胞よりの剝離はなく，文支持細胞についても 胞体の形態異常はなく，基底膜よりの剝難は認められな かつた，Reissner 氏膜は直線状で著変なく，シンバ管 内には赤血球の遊出は認められなからた（第 1 度 a 病 変).

曝露時間が 20 分となると有毛細胞の損傷範囲は 5.5 $14.0 \mathrm{~mm}$ となり少し拡大されていたが, 病変の程度は核 の pyknosis の他は著変がなかつた (第 1 度 a 病変).

曝露時間 30 分例に打いては，損傷の籍囲は 5.2〜14.0. $\mathrm{mm}$ であつたが，損傷の度合いはや〉強く有毛細胞の 腫掁と核の pyknosis とが現われていた. Tunnel 腔や Nuel 腔には amorphous hyalin exudate が現われて いたが、これは acoustic traumaによる産物である (第 1 度 $\mathrm{b}$ 病変):

音圧 $105 \mathrm{db}, 10$ 分刺激例では, 病変の範囲は 5.3〜 
第 1 表 $1000 \mathrm{zps}$ 刺激群成籍一覧表

\begin{tabular}{|c|c|c|c|c|c|}
\hline \multicolumn{3}{|c|}{ EXPOSURE } & \multicolumn{3}{|c|}{ INJURY } \\
\hline No. & Db. & Min. & $\begin{array}{l}\text { Distance (min) } \\
\text { from Basal End }\end{array}$ & Turn & Grade \\
\hline $\begin{array}{r}1 \\
2 \\
3 \\
4 \\
5 \\
6 \\
7 \\
8 \\
9 \\
10\end{array}$ & $\begin{array}{l}100 \\
100 \\
100 \\
105 \\
110 \\
110 \\
110 \\
110 \\
110 \\
115\end{array}$ & $\begin{array}{l}12 \\
20 \\
30 \\
10 \\
2 \\
5 \\
10 \\
30 \\
60 \\
20\end{array}$ & $\begin{array}{l}5.4=12.5 \\
5.5=14.0 \\
5.2=14.0 \\
5.3=14.0 \\
6.8=14.3 \\
6.0 \simeq 13.0 \\
5.2=12.6 \\
5.0=14.0 \\
3.0=14.3 \\
6.8=13.3\end{array}$ & $\begin{array}{l}I-U \sim 11 I-I \\
I-U=11 I-U \\
I-U=111-U \\
I-U=11 I-U \\
I-U \sim 11 I-U \\
I-U \sim 111-L \\
I-U=11 I-L \\
I-U=11 I-U \\
I-I=111-U \\
I-U=111-U\end{array}$ & $\begin{array}{l}1-8 \\
1-8 \\
1-b \\
1-8 \\
1-8 \\
1-8 \\
1-b \\
2 \\
3 \\
1-b\end{array}$ \\
\hline $\begin{array}{l}11 \\
12 \\
13 \\
14 \\
15 \\
16 \\
17 \\
18 \\
19 \\
20\end{array}$ & $\begin{array}{l}115 \\
120 \\
120 \\
120 \\
120 \\
120 \\
125 \\
125 \\
125 \\
125\end{array}$ & $\begin{array}{r}30 \\
2 \\
5 \\
10 \\
17 \\
60 \\
10 \\
13 \\
15 \\
30\end{array}$ & $\begin{array}{l}4.4=13.5 \\
3.0=14.0 \\
3.2=13.8 \\
3.0=14.0 \\
3.4=12.8 \\
3.0=14.2 \\
5.5=13.8 \\
5.6=14.2 \\
5.5=14.0 \\
2.0=14.5\end{array}$ & 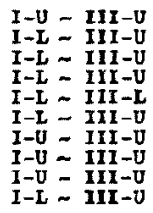 & $\begin{array}{l}3 \\
1-8 \\
1-2 \\
1-b \\
2 \\
3 \\
1-b \\
2 \\
2 \\
3\end{array}$ \\
\hline $\begin{array}{l}21 \\
22 \\
23 \\
24 \\
25 \\
26 \\
27 \\
28 \\
29 \\
30\end{array}$ & $\begin{array}{l}125 \\
130 \\
130 \\
130 \\
130 \\
135 \\
135 \\
135 \\
135 \\
135\end{array}$ & $\begin{array}{r}60 \\
5 \\
10 \\
20 \\
60 \\
3 \\
5 \\
6 \\
10 \\
25\end{array}$ & $\begin{array}{l}3.0=14.5 \\
5.9=12.5 \\
2.0=14.0 \\
2.0=14.0 \\
2.0=14.0 \\
5.5=13.0 \\
5.0=13.8 \\
3.0=13.8 \\
3.4=14.2 \\
3.0=13.8\end{array}$ & $\begin{array}{l}I-L=11 I-U \\
I-D=111-I \\
I-L=111-U \\
I-L=111-0 \\
I-L=111-U \\
I-U=1111-U \\
I-U=111-U \\
I-L=111 I-U \\
I-L=1111-U \\
I-L=I 1 I-U\end{array}$ & $\begin{array}{l}3 \\
1-b \\
3 \\
3 \\
3 \\
1-b \\
2 \\
2 \\
2 \\
2\end{array}$ \\
\hline $\begin{array}{l}31 \\
32\end{array}$ & $\begin{array}{l}135 \\
135\end{array}$ & $\begin{array}{l}30 \\
60\end{array}$ & $\begin{array}{l}4.0=14.0 \\
2.6=14.4\end{array}$ & $\begin{array}{l}I-I-I \\
I-L\end{array}$ & $\begin{array}{l}3 \\
3\end{array}$ \\
\hline
\end{tabular}

14.0.nm であつたが, 病変の度合いは軽症であつて有毛

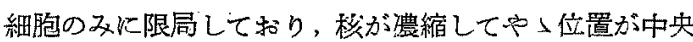
にずれていた，支持細胞や mesothelial cells の病変は 認められなかつた（第 1 度 a 病変).

\section{$110 \mathrm{db}$ 刺激群}

曝露時間 2 分例では，損傷範囲は 6.8〜14.3mm で， 有毛細胞特に外有毛細胞の椟の pyknosis が主要所見で あり，懪露時間 5 分例では，損稘範囲は 6.0〜13.0 mm で, 轻度病変であつた（第 1 度 a 病変）。

懪露時間が10分となると，病变の程度は更に强くな り，10.0 11.0 mm の暻かの区域ではあるが有毛細胞の 胞体間の hyalin exudate が著明となり胞体がや】不明

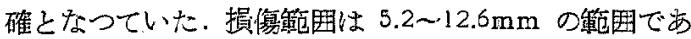
つたが，交持細胞の变化は少なく mesothelial cells の 減少は認められなかつた（第 1 度 b 病変）。

しかし，曝露時間が 30 分となると変化は更に強くな つていた、すなわち，10.0〜11.5mm の籍囲では有毛細 胞の雷掁が強くなり，細胞壁が不明確となり，病理租繶 所見上は第2 度の病变を示していた，病变の全簛围は

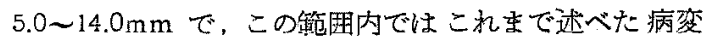
乙同㥞に第 1 度の変化が観察された(第 2 度病変).

曝露洔䦩 60 分例では，有毛細胞と支持細胞とは8.2 $10.9 \mathrm{~mm}$ の筙囲で消失して和り，細胞の崩瓖は 5.0

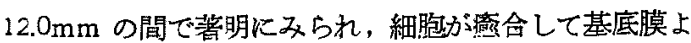

りの剝離を認める部分もあり，tunnel 腔は虚脱してい た、病変の範囲は広く $3.0 \sim 14.3 \mathrm{~mm}$ であつた（第 3 度 病変) (第 5 図).

更に音压を $5 \mathrm{db}$ 增加して $115 \mathrm{db}$ ，とした場合，曝露 時間 20 分では，有毛細胞や支持細胞には軽度の損傷が 6.8〜13.3mm の範囲に認められるのみであつたが(第1 度病変 b), 曝露時間が 30 分となると, 一部に病変が急 激に強く表われていた，おなっら，病変の範用は 4.4〜 $13.5 \mathrm{~mm}$ で有毛細胞の棪の pyknosis が認められ，5.7〜

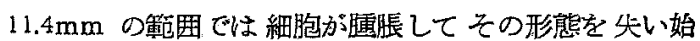

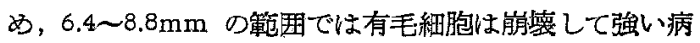
変を示していた．芳持細胞の変化は，有毛細胞にはょ平

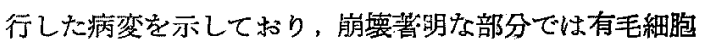
之混然一体となり，夫々の細胞の判別ができないものが あつた. Mesothelial cells は, 5.5〜12.0 mm の範囲て 減少して为り，特に 7.3〜11.4mm の範用では消失が認 められた（第了度病変）。

$120 \mathrm{db}$ 刺激群:

曝露特間 2 分例では損傷範困は意外に広く $3.0 \sim 14.0$ $\mathrm{mm}$ であつたが，その病変の度合いはきわめて軽度で

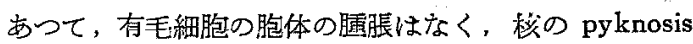
が認められる程度であつた（第 1 度 a 病变).曝露時間 5 分例では，3.2〜13.8 $\mathrm{mm}$ の範国にこれと大差ない所見 がみられ（第 1 度 a 病変），曝露時間 10 分例では，更 に有毛細胞の胞体が軽度に㯰脹し, mesothelial cells の減少が 10.5 mm 附近に見られた。唄傷範西は 3.0 $14.0 \mathrm{~mm}$ であつた（第 1 度 b 病変）。

瀑露時間の最も長い60分例に拈いては，病变の範囲 は最も短い2 分例之殆んど同様で，3.0-14.2mm であ つた，有毛細胞や支持細胞の消失は認められなかつた

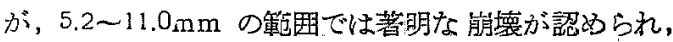
この箸囲内の細胞は一つの塊として基底膜から遊離して その上にのつている形であつた（第3 度病変）(写真6).

$125 \mathrm{db}$ 刺激群

曝露時間 10 分例では，5.5〜13.8mm において有毛細 易の檬に pyknosis が認められ，6.5〜 12.0mm の範囲 では有毛細胞と支持細胞の夫々の胞体に軽度の腫脹をき たしており， mesothelial cells の減少は 8.0〜 $12.0 \mathrm{~mm}$ の籍田に認められた（第 1 度 b 病変）．懪露時間 13 分 では，第 1 度 a 病变が $5.6 \sim 14.2 \mathrm{~mm}$ K, 同 b 病変加 $6.2 \sim 12.0 \mathrm{~mm}$ に認められ，最も強い病変は有毛細胞の 喢脹, 秋の pyknosis ないし檬の消失が. 10.0〜 $11.0 \mathrm{~mm}$ の籁国に㑇められた，支持細胞の病変としては，8.0〜 


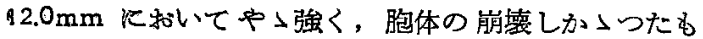
の，核の位置異常などが認奴られた。. Mesothelial cells の病変区域は広く，7.5 13.0 $\mathrm{mm}$ に消失ないし著犋な 滅少が認められた（第 2 度病変）。

懪露時間 15 分例は，これと大美ない所見で，損傷範 囲は 5.5〜14.0mm であつたが (第 2 度病変)，30 分例 では病変は非常に強く表われていた。すなかち，2,0〜 $5.0 \mathrm{~mm}$ の範囲では， 細胞の変伦はそれ程著明ではない が，被蓋膜の直下に赤血球が浮遊しており。有毛細胞得

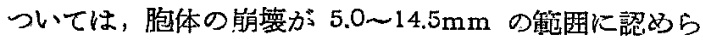
れ，核は pyknosis 㕛は消失がみられた，最も大きな变 伦は有毛細胞の消失であって 7.5〜9.5mm に認められ た（第 3 度病変），懪路時間 60 分例では，有毛細胞の蕾 脹は 3.0 14.5mm 飞, 䏴壊は $5.5 \sim 11.5 \mathrm{~mm}$ の夫々の 範囲に著明であつたが，こつに興味あるのは30分例で 細胞の消尖が認められたのに対し，60分例では認めら なかつたことであり，これは恐らく個体差の存在による ものかも知れない，な招，60分例では，交持細胞の崩 壞之 mesothelial cells の消失とは, 有毛細胞能壊の程 度とほら゙比例して認められたが mesothelial cells の減

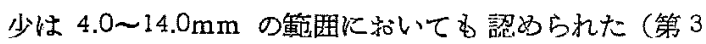
度病变)。

$130 \mathrm{db}$ 刺激群:

曝露時間 5 分例では，有毛細胞の pyknosis のみをき

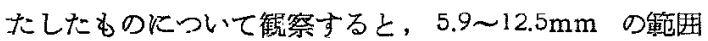
《認められたが, 有毛細胞が軽度に婳脹し, 細胞間に hyalin exudate を生じたものは $8.3 〜 12.0 \mathrm{~mm}$ の範团 であつた（第 1 度 b 病変). 曝露時間 10 分例では, 病 変は急激治く現われていた。すなわち，有毛細胞の胞

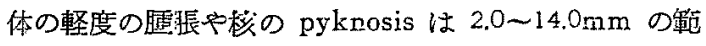

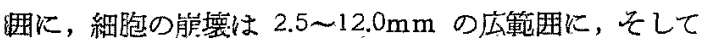

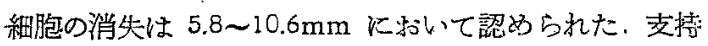
細胞については，有毛細胞の 所見に活ざ比例していた が，Deiter 氏細胞は基底膜から剩離し始めHensen 氏 細胞々 Claudius 氏細胞との間には間隙点生じ，有毛細 胞の消失の部分ではなな゙ mesothelial cells が認めら れた. 内外ッンバ管内には多数の赤血稆訲認められ，血

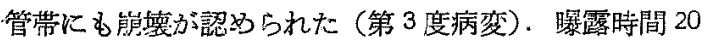
分例では 2.0 14.0mm の範团に病変がみられたが著明

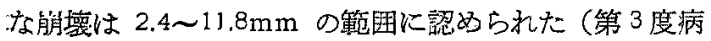
变). 瀑露時間 60 分例では $2.0 \sim 14.0 \mathrm{~mm}$ の範困に病变 を生じており，有毛細胞中支持細胞に渚明な崩壊が認め られ 6.0 10.8mm の範囲では消失が認められた（第 3
度病签)。

\section{$135 \mathrm{db}$ 刺激棓}

曝露時閒3分例では，有毛細胞の軽度の婳張が5.5 13.0 $\mathrm{mm}$ の範囲に認められ, 支持細胞の軽度缰脹之 mesothelial cells の減少とが 9.0〜11.0mmに認められた(第 1 度 $\mathrm{b}$ 病変). 曝管時間 5 分例では, 病変範围住ほ心゙同 橡で 5.0 13.8mm であつたが，有毛細胞と支持細狍と の軽度腫脹と，胞体間の hyalin exudate が認められ， 又 mesothelial cells の減少は 7.0 13.0mm の簛囲で, 特に 9.0〜11.0mm に衿てて著明であつた(第 2 度病変)。 曝露時間 6 分例では，病变の範囲は $3.0 \sim 13.8 \mathrm{~mm}$ であ つたが，特に 5.6〜11.5mm では有毛細胞の臑涱強度と なり，支持細胞㶤いても Deiter 氏細胞は基底膜より 煣離し始的，又 Hensen 氏細胞と Claudius 氏細胞之 の間には間隐を生じ，支持組織としての構造を失い始め

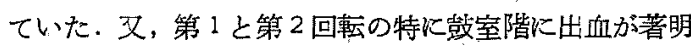
であつた (第 2 度病変)，曝露時間 10 分例では，有毛細 胞の病変の範囲は 3.4 14.2mm で, 有毛細胞と支持細 胞の崩壊は 5.9〜8.6mm の範囲に認ひられたが, 細胞 の消失はなからた. Mesothelial cells の消失は 6,0 $13.0 \mathrm{~mm}$ の広域に認められた（第 2 度病変）。曝露時間 30 分例では，病変は $4.0 \sim 14.0 \mathrm{~mm}$ の锤围に纵じてい

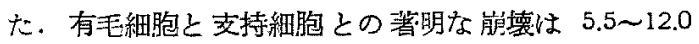
$\mathrm{mm}$ の範用であつたが，リノバ管内の出血が著朋であ って, 基底膜の下に恰も mesothelial cells の上うに赤 血球の並んでいる所もあつた（第 3 度病変）(写真 7 ).

本群最大の刺激強度である 60 分例では，有毛細胞の 病変は basal end 上り 2.6〜14.4mm にわたる広範囲 に生じていた，この範囲では，有毛細胞性軽度の胞体の 腫張と核の pyknosisを認めたが，支持細胞の変化は認 められない. Mesothelial cells の变化も少ない. 更に 〔.4 12.9mm の範围では有毛細胞，支持細胞共に著明

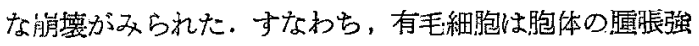
く，細胞壁の明確さを欠さ，支持細胞について子埂脹 して構造が不明破となり，基底膜上り剝滩し始め，又 mesothelial cells の消失も認められた. 最飞強い変! は 6.0〜11.2mm の範囲にみられた有毛細胞や文持細胞 などの消失であつた（第 3 度病変）(第 6 図，写兾 8 と 9).

D. $2000 \mathrm{cps}$ 刺激鹤:

$110 \mathrm{db}$ 刺激覀

曝露時間 20 分例では，有毛細胞の軽度蕾脹と愁の pyknosis の所見が，4.0〜 12.5mm の簛囲に認められた 
が，7.0〜10.0mm では更に支持細胞を腫脹して 胞体が や\不明瞙となり, 又この䉪囲内では, mesothelial cells 減少していた (第 1 度 b 病変). 曝露時間 60 分例では，有毛細胞と支持細胞の 崩壊範围は 5.0 11.5 $\mathrm{mm}$ に認められたが，高度の崩壊は 7.5 9.0 $\mathrm{mm}$ の範 因に生じて拔り，mesothelial cells については 5.5〜 $10.8 \mathrm{~mm}$ に执いて消失していた（第3 度病変）。

$120 \mathrm{db}, 125 \mathrm{db}$ 刺激群

$120 \mathrm{db}, 5$ 分刺激例では, 有毛細胞の損傷範囲は 4.0 $13.5 \mathrm{~mm}$ であつたが, 細胞の崩襄は $6.8 \sim 10.8 \mathrm{~mm}$ の区 域に生じて扔り，この範囲内では tunnel 腔に hyalin exudate を生じ，核の pyknosis む著明に現われてい た. 支持細胞の崩環と mesothelial cells の減少とは, 7.0 9.0 mm に执いて最も著明であつた（第 2 度病变）。 $120 \mathrm{db}, 60$ 分例では有毛細胞と支持細胞の 崩壊は 4.5

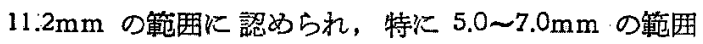
では, 細胞消失直前の像を示し; 又 7.0 9.5mm では, 有毛細胞と交持細胞の胞壁は湥合してしまい, Deiter 氏細胞は基底膜より遊離していた（第 3 度病変）(写真 10).

$125 \mathrm{db} 30$ 分刺激例の病変範囲は $3.0 \sim 13.0 \mathrm{~mm}$, Corti's organ の崩壊範囲は $3.5 \sim 11.5 \mathrm{~mm}$, 消失範囲は 6.2 $\sim 8.2 \mathrm{~mm}$ であつた (第 3 度病変). 60 分例では, 病変 は更に basal end に偏り，損傷範囲は 1.8 14.8mm の広範困であつたが，細胞の崩壊は $2.0 〜 11.0 \mathrm{~mm}$ に認 め巨れ，特に細胞壁不明という强い崩壊は7.0〜11.0 $\mathrm{mm}$ に和いて認如られた。細胞の消失は $6.0 \sim 8.0 \mathrm{~mm}$ にみられた(第 3 度病変)。

$130 \mathrm{db}$ 刺激群

曝褃時間 10 分例 では, 病変の範用は $5.0 \sim 14.8 \mathrm{~mm}$ で, 有我細胞と支持細胞の葄罴は 6.2 11.0 mm に, 消

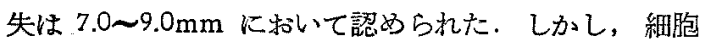
に注変拒の少ない $2.0 \sim 5,0 \mathrm{~mm}$ の Corti's organ の上 には赤血偢が認められ，この範囲の Corti's organ とり ンバ夜の振動との間に密接な関係のあることを示してい

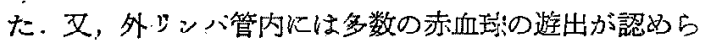
れた (第 3 度病変). 䀧露時間 20 分例では有毛細胞と支 持細胞は $5.7 \sim 11.0 \mathrm{~mm}$ の舵囲に蛙いて崩壊し, 殊に 6.3〜 7.0 mm では Deiter 氏細胞の崩壊㹮明で，一部に 消失の部位も認められた。細胞の消失範围は7.0 8.6 $\mathrm{mm}$ であつた (第 3 度病変). 曝露時間 25 分例で心, 有毛細胞と支持細胞の消尖は $5.6 〜 6.8 \mathrm{~mm}$ の範囲であつ たが，細胞全部が消失している所と，tunnel 腔は存在
し特に外有毛細胞とその支持細胞とが消失している所と があつた（第 3 度病变）。

\section{$135 \mathrm{db}$ 刺激群}

曝露時間 4 分例では, 有毛細胞の病変は 2.2 14.5mm の範囲に生じていたが，この範团では細胞の䭪脹は認め られるが比較的原形を保つており，核では pyknosis が 認められた：細胞の崩珐は $6.0 \sim 10,8 \mathrm{~mm}$ の部位に認め られたが，最る著明な変化は 6.3〜8.5mm の区域にみ られた Corti's organ の消失であつた. Mesothelial cells は 5.0 12.0mm の範囲で 減少ない乙消失が 認め られた (第 3 度病変)，懪露時間 6 分例では，細胞の崩

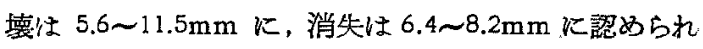
大(第 3 度病变). 瀑露時間 10 分例では, 病変は 1.8 $13.0 \mathrm{~mm}$ の範围で, 細胞崩壊は $4.8 \sim 10.7 \mathrm{~mm}$ で著明で あり．そして 5.2 7.8mm の稪围に細胞の消失が 認め られた。 1.8〜4.0 mm の部位では，外有毛細胞の特に外 側 2 列に和いて㚊の pyknosis が著明であつた（第3 度 病変) (第 7 図).

瀑露時間 20 分では，有毛細胞と支持細胞の消失は 5.0 〜.2mm であつたが, mesothelial cells は 5.0〜10.0 $\mathrm{mm}$ の広域に批いて消失していた，有毛細胞は 2.2 $10.7 \mathrm{~mm}$ の範囲で崩壊して塊状となり，細胞壁は不明 で, tunnel 腔には exudate が充満していた（第3度 病変). 踏露時間 30 分では, Corti's organ の病変は 1.5 14.0mm の広䈟囲で，有毛細胞之支持細胞の崩壊 は 4.6 10.0mm に, 消失は 5.5 7.2mm であつたが， mesothelial cells の消失は 4.6 11.0mm の広域沉及 んでいた (第 3 度病变).

つぎに，曝露時間を延長するとどの程度の損傷をきた すかを知るために，135db 2 時間刺激の実駼を行つた。

この例では，殆えど全域の Corti's organ に病変が 認められた。すなおち oval window に近い部分であ Corti's organ の崩票は著明で，例えば $2.2 \mathrm{~mm} の$ Corti's organ は写真 11 のよ5に, 有毛細胞の 崩壊著し 々，支持細胞も変化し，殊化 Claudius 自細胞は腰脹し て冰状に膨化して 基底膜より㓦離寸前の形を示してい た.この標本の附近では, Claudius 氏細胞が scala media 中に浮遊しているものもあつた (第 3 度病変).

E. $4000 \mathrm{cps}$ 刺激群

$110 \mathrm{db}$ 刺激硗

曝露時間 2 分例では，有毛細胞の胞体の軽度腫脤と秋

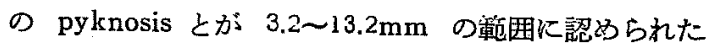
が, その他仙は著变を認めなからた（第 1 度 a 病変）. 
曝露時間 3 分例でも, 病変範囲は $3.0 \sim 13.0 \mathrm{~mm}$ に有も 細胞の稼の pyknosis のみが認められ，支持細胞や mesothelial cells 潧変をみとめなかつた（第1度a 病変). 曝露時間 30 分例では, 有毛細胞と支持細胞は共 《胞体の軽度の德脹之核の pyknosis とが $3.0 \sim 13.0 \mathrm{~mm}$ の籍囲に生じており, 細胞の崩壊が $6.2 \sim 9.8 \mathrm{~mm}$ の範囲 《認められた：この範囲の有毛細胞とDeiter 氏細胞と Hensen 氐細胞とはすべて塊状に痊合していたが，基底 膜よりの鶨離は認められなかつた。最も著明な崩壊は 6.2 7,2mm に認められ，こつでは塊となつた有毛細胞 と支持細胞とが基底膜より劧離している部分もあつた (第 3 度病変).

$120 \mathrm{db}$ 刺激群

曝露時間 3 分例では, 病変は $3.3 \sim 13.5 \mathrm{~mm}$ の範围比 有毛細胞の 軽度腫脹と核の pyknosis が認められ, 5.0 〜 7.5mm の範囲に扎いては, 支持細胞の軽度腫脹が認 められた (第 ! 度 b 病変). 瀑露時問 15 分例では, 1.4 〜11.7mm の範囲に有毛細胞の核の pyknosis 認め, 文 4.6〜 10.5mm の範囲では細胞の崩壞が著明となり， 特に 7.0 8.0mm では支持細胞が 基底膜より剥離して いた. 最も強、病变は Corti's organ の消失であつて, これは 5.8〜 7.2mm において認められた(第3 度病変). 曝露時間 30 分例では，著明な Corti's organ の崩墂が $5.5 \sim 11.0 \mathrm{~mm}$ に, 同消失が $7.7 \sim 8.5 \mathrm{~mm}$ の範囲に認め られた (第 3 度病変).

$123 \mathrm{db} 60$ 分刺激例

有毛細胞の婳脹や核の pyknosis は 1.4 13.7mm の 籍团でかなり basal end に及んで拈り, Corti's organ の崩罱は 1.8 11.0 $\mathrm{mm}$ で, 又同消失は 2.2 6.6 $\mathrm{mm}$ の 筙囲すなから第 1 回転の汪ら゙全域に及んでいた（第 3 度 病变).

F. Critical intensity について

Acoustic trauma $Z_{\text {wislocki }}{ }^{7)}$ の云うように広義 飞解釈して, Corti’s organ における損傷程度を病理形 態学的に観察して，可逆性と思われるるのと，不可逆性 と思われるものとに分類して，両者の間に境界線る求め ろるか否かを上記の実験結果から検討してみた。

もちろん，Corti's organ に括ける損傷は刺激音圧と 刺激時間との両因子流響されるが，そのうちでる大き な影響因子は音圧である所から，損稘部位が元通りに回 復する可能性のあると思われる可逆性の限界点といら意 味で,こつでは critical intensityという言宾を使用し た.たざし、こ১にいら critical intensity は,一般に
用いられている意味よりは広義のものである。

䈗密な意味で critical intensity 病理形態学的に求 ぬることは甚だ困孉ではあるが，病理組織学的所見か ら，音響曝露により生じた損傷が回復されるであろうと 推定される点を想定し，これを結んで critical intensity line と考克た.この曲線を求めるために $1000 \mathrm{cps}$ につ いて, Corti's organ の有毛細胞と支持細胞の形態学的

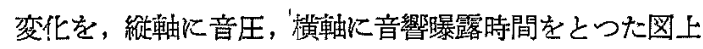
に現わしたのが第8図である．この図で，永久聴力镍失 をきたすと推定される点すなわち×印（第 3 度病変）， $\triangle$ 印 (第 2 度病変) 叔よび病変は少ないが聴力損失が㲓 るであろうと考党られる○印（第 1 度 b 病变）の存在 する部位と，正常聴力に回復することができると考えら れる点○印（第 1 度 $a$ 病変）の存在する部位との間を 分劃する線がいわゆる critical intensity Iine であ る、第 8 図中の点線がこれを示し，この点線よりも左方 は病変の可逆性を，右方は不可逆性を示している.

第 8 図 $1000 \mathrm{cps}$ 制激稏の Corti's organ の損㑑照

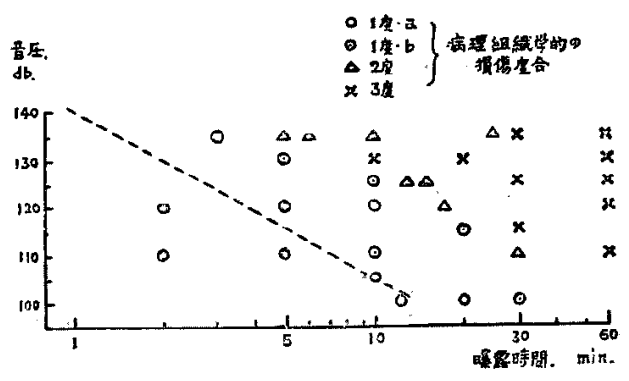

G. 損傷の局在性について

基底膜上の音響による局在性をしらでるために， graphic cochlear reconstruction を行つて作図したグ ラフを，第 レ度病变吪と第 2 度および第 3 度病変群の 2 群に分けた。解剖学的損傷を数字に置き换えることは甚 た困難ではあるが，たとえば，組織的炕第 3 度の病変を きたしている部位を(+3)といらように，その病変の 程度を示寸数字をその損傷の指数として，基底膜上の各 部位について病変の程度の度合別にこの指数の和を求め たのが第9図である。

実線は，有毛細胞の変化が第 1 度に属するもの 14 例 より集計して得られたるのであり，点線は第 2 度 8 例， 第 3 度 10 例, 合計 18 例上り求めて, これを点線と比較 する便宜上，それを1/2倍したものである。この図から 1000 cps 刺激群汇和ける Corti's organ の第1 度病変 
の中心性 10.0〜10.6 mm の部位であると考え巨れる。

第9図 $1000 \mathrm{cps}$ 制激群の Corti's organ 損侮の発生分布図

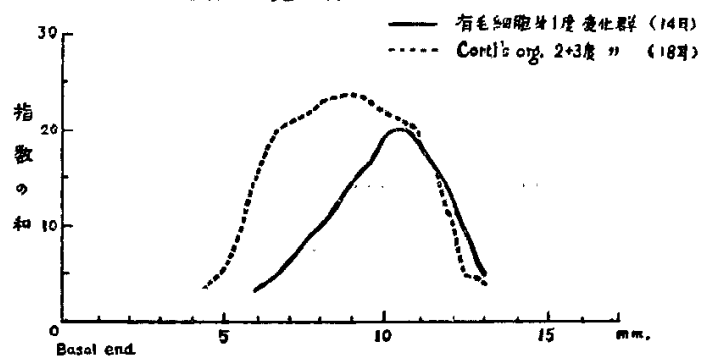

一方, 刺激強度の弱いものについて, 病变の局在性を 検謤してみると，次のように 10.0 11.0mm の附近が 最も損稘され县いのではないかと推定された。すなか b， $110 \mathrm{db}, 30$ 分刺激例では 10.0〜 11.5mm に有毛細胞 の胞壁不明磪となり，120db，10 分剌激例では $10.5 \mathrm{~mm}$ 附近の mesothelial cells の減少が双ら礼, 135db, 3 分 例では，9.0〜11.0mm に支持細胞の軽度㬈脤と mesothelial cells の減少方認められた。

つぎに，刺激強度の增大に伴う病変の拡か゚りかたを微 察すると，これは左右刘称性に拡がるのではなくて， helicotrema よりもむしろ basal end の側により大き くずれる傾向がいちじるしく（第9図）、第 2 度括よび

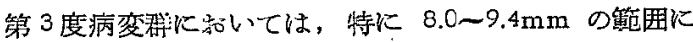
椇傷の中心が現われた。

$2000 \mathrm{cps}$ および $4000 \mathrm{cps}$ 刺激群についても，損傷の 局在性をしらべるために $1000 \mathrm{cps}$ 刺激請: 同槉の方法 によつて作図したのが第10図である：この図では（第 2 度十第3度) 病変群を図示してあるが, 此較の便冝上, $1 \mathrm{co0} \mathrm{cps}$ の第 2 度小よび第3度病変群のそれを园示した。 第 10 図からみれば，損鹪の中心は $2000 \mathrm{cps}$ 刺激群では $7.0 \sim 7.8 \mathrm{~mm}, 4000 \mathrm{cps}$ 刺激では $6.4 〜 7.2 \mathrm{~mm}$ に現わ れていた。

第 10 図 $2000 \mathrm{cps}$ 扣さび $4000 \mathrm{cps}$ 刺激群の Corti's organ 椇烈の発生分有図

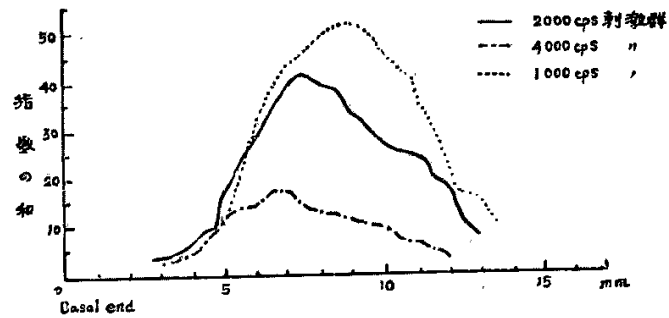

\section{IV. 考繁}

正常な聴器を有すると考えられる動物に音響刺激を与 え; いわゆる音䝷性外傷を生ぜしめた聴器を病理組織学 的に観察するこれまでの実験的研究の多くは，動物を無 麻䣦のもとで且つ自由音場に就いて進められてきた。乙 かしこのよらな刺激条件一下では，豉膜に加方る央際の刺' 激音压が不明確であり，したがつて束激音生と㯖器障害 との関係が正確に 表現されていないことになる。そこ

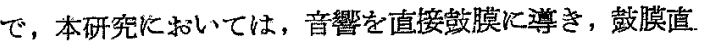
前の音玉を测定する方法をとつたが，こつで先ず，本夷 鍙方法について都察してみたい。

\section{A. 実験方法について}

從采の多くの研究者達が選んだ無麻酔，自由音暘によ

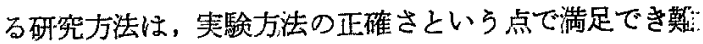
いものが多い，守なわら，音暨瀑露中被実験動物は集合 して音響に対する防挷的体位をとりやすく，又等独でも。 常に頭位を移動㕱しめるので，果して聴繁に対してどれ，

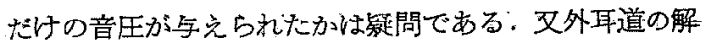
剖学的構造の上からスても, 自由音場で測定された音圧 と椇膜声前で测定された音开との間にはかなり大きな相 違があると思われる。

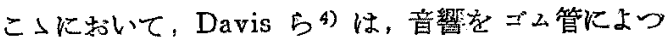
て直接豉朝に導入し，その先端に probe-tube microp-

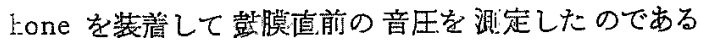
が、これは従来多くの研究者達が用いた指示騒音計以よ る音珐測定法上りるはるが改善されたものというべき であろう、そこで, 本硕究に执いてもこの方法を採用し て，音䇾を金属管と耳鏡により鼓膜に直接導き，さらに probe-tube microphone を使用して，実験中随時鼓膜 直前の刺激音任を湘定することにより，自由音場の方法 による欠点ささけた。

また笑験動物には全例共 urethaneによる全身麻酥を 行つてから音響刺激を加えたが，こっで考慮すべきは中

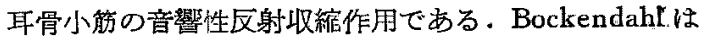
中耳骨小筋は音響の持統する間は収縮状態にあると述心 たが，Luesher は鐙骨筋は妈い連綄音に対して 最初に 瞬間的に収縮するのみであり，中等度の音垫では数回の 連綕的収縮が認められ，強い音響によつては持緢的に収 縮すると報告し，また Lindsay らはは，鐙骨筋の収 縮は防纂機構として作用する生理的現象であり，これは 全身麻櫭によつて消失すると述べている. Davis ら全 身麻唒により，100〜10000cps のいかなる純音に対して 子中耳骨小飰の反射性収縮はみられないと述べている点 
などからみて，本实龭に扣いてる，全身麻酔によつて中 耳骨小脇の反射性収縮を除外することにより，内耳比対 する音響の值接の影響をを探寗するように力ぬた。

Urethane の聴器に対する薬物としての中毒作用は， Davis ら 4)によれば全く認められないという。

刺激実験室としては，既述したような防音箱を㕅上に 浮かせて使用したが，箱の容禎が大きく且つ刺激時間が 短いので，床の振動，その优の環境婪件の聴器に対する 影響は考慮する必要はないと思われる。

\section{B. 実験成續について}

聴器に対する音響刺激の影響は，主に刺激音の强さと その持続時間之に支配されるが，その汪かに性個体の抵 抗の大小炕よても吝配されることは，よく知られた雲 実である。これは聴覚のみならず他の感覚器官に和いて む認奶られた事実であり，一般的にいって， $R=f$ (IT) で表わされる..たごし $\mathrm{I}=$ 刺激の強さ， $\mathrm{T}=$ 刺激時間, とする。この場合 I が極端に堌大すれば， T は小さく

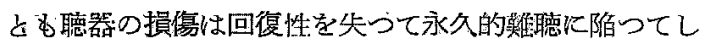
まう事実す，私共が平菜臨床で経験するところである． これを実験的に証明した成續も数多く報告されている， 私もこれ追試して，135db，3 時間，7 日間連続という界 常に強い刺激音によつて，モルニットの Corti's organ が局部的炕完全に消失した成績をみている（写真 12）。

しかし，私の興味は，聴器が永久的損傷宿る一步前 の状態, 云いか兄れば, 病変の可逆性之不可逆性との限 界が，刺激音の強さ之刺澈時間の長さの関連飞和いて； 病理組織学的に求めら机るがどうかといら点にあるの で，この観点から筧ず本実騟成績について考察してみた W.

この目的のた妨には，病理組織学的所見に現われる比 輍的弱い刺激条作から，しだいに強い刺激采件へと研究 を進めていって，その傷害部位の初発部位やその拡大 方向と，剌激音の周波数との関係を graphic cochlear reconstruction 法により，従来の方法よりも詳細に究 昵するよらに妢うした。

Corti's organ に現われる acoustic trauma の病変が 高度で，たとえば Corti's organ の崩壊（第２度病変） や消失（第 3 度病変）のみられる上らな場合性，明かに 木可逆性変化と断定することができるが，有毛細胞や支 特組織などに現われる 軽度病変 (第 1 度 a 括よび第 1 度 $\mathrm{b}$ 病変)から可逆性か否かを明確に決定することは

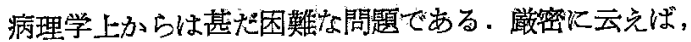
いつたえ放る強さの音響刺激をうければ，正常な所見を
呈すると思われる Corti's organ でも譏能的には聴力 障害を和こしているだるうことは考学られらるところで ある、しかしこっでは、形態学的立楊から，主に有毛細胞 の变化を主眼として観察し，Corti's organ が正常筑围 内と思市れるもの就よび有洰細胞の軽度の変化を゙第 1 度 a 病変として，これを可逆性変化とし内外有毛細胞の整 度の通脹，核の变位西るい悚度の pyknosis のあるも の，またこれに Deiter 氏細胞や Hensen 氐細胞など。

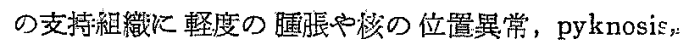
mesothelial cells の軽度の滅少のみられるもの去での 範囲を第 1 度 b 病変とし, これ恃恐らく一部は回復し らるが，永久的匴整として回復しないものと推定した。

そこで，刺激条件が弱刺激からしだいに增大するにっ。 れて，Corti's organ に执ける損傷の括こり易い部位亡 その度合いは，どのように進展するが検討してるる必 要がある。

Corti's organ の各細胞の損傷順位については, 一般 的には，外有毛細煦，内有毛細胞，支持練胞の順火和か されるといるれている，私の成烧では，弱刺激の場合 (100db 20 分以下, 又は $110 \mathrm{db} 10$ 分以下) にみられる 变化は，まず外有毛細胞作，ついで内有毛細胞に現われ るが，己の変作としては輆の位置異常や pyknosis，つ いで有毛細胞は膨化して細胞壁が不明確となる。この頃 から Hensen 氏細胞の膨化，pyknosis が現われ初め， Nuel 腔や tunnel 内撫構造の hyalin 上う物質が浸 出しはじぬ, pillar cells その他の支持細胞の変形や萠 苓が执こり，mesothelial cells あまばらになりある い注消失する。従つて, mesothelial cells の消失性 Lurie ら2) のい.5ように acoustic trauma の初発所見: ではなく，有毛細胞の変化よりるかなり遅れて現われる 上うに思放れる。ささらに刺激が強をると, Corti's organ は基底膜より㓦離しはじる，終には Corti's organ 全体 が完全に消失するようになる，しかし基底膜と被盖膜は 最も損甥され難く、本実験中の全例に秃いて，色の損傷： は認められなからた。

有毛細胞と支持細胞とが Corti's organ のうちで最も 抵抗の弱い部分であり，基底膜と被蓋膜が強、抵抗を示 すことは，Katsuki and Covell 19) の位相差曊微鏡所 見によれば，後者は練か心線維を含む物質によつて構成 され，その化学成分す他のもの之異なることからもうな ずけること思䃼る。

このような形態学的変化を基碟として，第小表の実験 成績及び第 8 図をみると，病理組織学的にみた可逆性変: 
化と不可逆性変化との間に一つの分劃線が引かれること そなるすすなわち，刺激の強さと刺激時間の長さとをそ 侊ぞれ因子とする一つの直線である。これがこつにいう 広義の critical intensity line (限界强度線) である。 したがつて acoustic trauma に嵌いては，刺激の強さ はむちろん重要な影響因子ではあるが，刺激時間の長さ あをた重要な役割を演ずるものである，Davis ら4)の 行つた束激時間 10 秒から 5 分迄の実験では, 刺激時間 よりも刺激の强さがより䯓要な影響因子であると述べ Rüedi あ) もこれを支持しているが，私の実験の場合のよ 亏に，刺激時間が 60 分飞る 達すると，刺激の強さの及 ならず，刺激時間必大きな役割を演ずることが分る。そ してこの critical intensity line を越光ない範囲内にお いては, Corti's organ の病理租織学的所見は正常範囲 内芮るか，あるい病的所見はあつてる極く軽度で， その機能も回復しらるものと考光られらる程度のもので 西る、この線をこえると，病変の回復性の見込はないる のと考えられる。

聴器損傷の回復については, Eldredg ら ${ }^{13)}$ によると 音㗽刺激の第 1 週に括いて既行わ行，本質的には 2 週 間で殆んど完全であるが,一方損傷細胞のその後の変性 山は更に長期にわたつて持続すると述べている，私の研究 で聴器に対する刺激後の経過をみなかつたのは,一つに 㹥实験方法が全麻酔によるわので，覮醒後正常な状態に 扎いて数週間これを飼充するのが困難であつたからであ り，又一つには，恥器損傷の程度を他覚的にしらべる場 佮，動物の聴力測定の方法として上く用いられるPreyer 䢸反応は確に簡単な方法ではあるが，これによつて作製 几た audiogram は聴器の解剖学的変化とは必らずしも 一致する結果:を示さなからたつめに，䂙究の方針として 音響刺激後即殺の方法をとつたのである。しかし，acoustic trauma の回復状況を完全に 追求するためには, 音響刺激後長時間動物を生存せしぬる方法を工夫しなけ ればならないがこれは今後の研究課題である。

刺激の弱い場合，聴党の機能々聴器損㑑に上る病理租 緎学的所見との関係は Davis ら4)によれば, 確実に聴 力の回復するものは組織的に全細胞はすべて正常の所見 を呈し，聴力が多分回復するであろうるのは，組維的に 忧有毛細胞の婳脹少なく，核の消失や exudate を認め る事があり，支持細胞では小空胞を形成する程度の病変 を示し, mesothelial cells はや」減少するという、私 杜，形態学的㳄みて，有毛細胞の変化を第一義的に考 え，その胞体の軽度の睡脹と榕の軽度の pyknosis まで
の变化を可逆性変化々推定した.

Corti's organ の解剖学的損傷之聴力之の関係は興味 あるところで，久保と志多 ${ }^{14)}$ 《租維的に Corti's organ に変化が認められなくても㯖力の抵下していることがあ ると報告しているし，灭 Spoendlin ${ }^{15)}$ によるとモルモ ットの聴器に弱い音響負荷を行つて外有毛細胞を観察す ると, 細胞内の mitochondria に小顆粒を生じこれ が正常動物より数が多くなり封入体を生じ，页細胞の基 底部に推ける神経終末の mitochondria が変化して膨 化したが，これら二つの変化が纵じてる他の細胞形成の 構造と細胞核とには特記すべき所見が認められなからた といら．この報告では, 細胞の变化と聴力との関係につ いては全くふれていないが, mitochondria が主として y ホ秒酸と燐脂質とからなり細胞必須成分をなす重要物 質であることを思えば，外有毛細胞の機能上何んらかの 变化をきたすのではないかと考党られる。

このように, Corti's organ の病理組織学的所見々聴 覚機能との間には, 病理組織学的㭘索の限界をこえて, あるいは電子顕微鏡的検慗にまたねばならない多くの未 知の問題が残されていると思われるのでこれらについ ては，な和，将来の矿究にまたねばならない。

次飞，基底膜に和ける病変の局在性とその拡がりかた について考察してみたい，

Acoustic trauma の発生部位と刺激音の 周波数との 関係をなるべく詳細に梌傠する意図のるとに，モルモッ トの基底膜の長さを测定し，graphic cochlear reconstruction を行つて, そのグシフ上に損傷部位をブロット

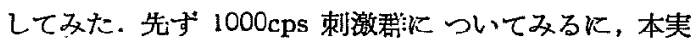

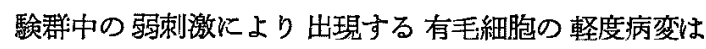
basal end か.ら $5.4 \sim 14.0 \mathrm{~mm}$ の範囲に現われるが，こ のうちです 10.0 10.6mm 附近に有毛細胞の最む著し い变化がみられる（第9図参昭）、したがつて，1000cps の弱刺激によつて，病理租織学的所見上最む強く反応寸 る Corti's organ の部位は basal end より 10.0 10.6 $\mathrm{mm}$ 附近（第 2 回転上部に相当する）にある. Lurie ら2) は 1000 cps $の$ frequency localization は第 3 回 朝下部に，また量島 ${ }^{16)}$ は蝸牛電気反応からみて，これ が第 2 回藷上半部にあるというが，私の成續はむしろ豊 島のそれに近いが，彼等は両者共に基底膜上の数値をる つて衰現していないので，私の成續と比較することがで きない.

次飞，刺激条件が增大すると，有毛細胞のみならず Corti's organ 全体に現加孔る变化も第 2 度，第 3 度と 


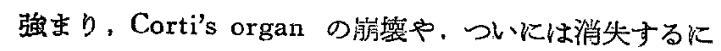
いたるものる現われるが，このような强い变化暨につい、 てみるに，この最も強い変化は， basal end より.8.0〜 $9.4 \mathrm{~mm}$ 附近に現われ, これに次ぐ変化も全体として helicotrema の方向より basal end の方向により きく移動する (第9図)、すなわち，刺激加增大しても， helicotrema の方向へは殆えど進まない(14.5mm まで) にも拘らず basal end に向つては basal end より 2.6 〜3.0 mm 附近まです病変恃拡大する。この事帮は，人 体実験に抦いて，刺激強度が堌大寸るにつれて，T.T.S. か溂激周波数上りも1/2 octave，次ぎには 1 octave の 周波数領域に順次移動し，下方周波数域には培しい变化 がないという，Davis や司城 ${ }^{17)}$ の成續とよく一致する. たぶし，本実軻成綘からは前述の 10.0 10.6mm 附近 が $1000 \mathrm{cps}$ の感受部位であるとは断定できない，何故 かとい光ば，中村，司城の人体寒鈳の成㐨からすれは， $1000 \mathrm{cps}, 100 \mathrm{db}$ (S.L.), 1 分間の剌激によつて T.T.S. の最大值は既に $2000 \mathrm{cps}$ に現われているからである.

次に, $2000 \mathrm{cps}$ の場合をみるに(第10図参照)，2000

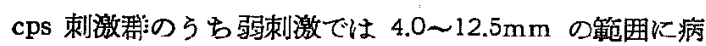
変が琴われ，そのらちでも強い変化は，basal end より 7.0 7.8mm 附近にみられ，刺激条件の增大寸るにつれ て, 病变は helicotrema の方向へは殆んど拡大せずせ いぜい $14.8 \mathrm{~mm}$ 附近まで), 專ら basal end の方向へ 问つて進行する ( $1.5 \mathrm{~mm}$ 附近まで).

更に，4000 cFs 刺激の場合には，弱刺激では basal end より $3.0 \sim 13.0 \mathrm{~mm}$ の䍄团に病変が現われ，そのう ら強、病变の中心は, basal end より 6.4 7.2mm の 附近に現われ，刺激条件が堌強すれば，病变は basal end から $1.4 \mathrm{~mm}$ 附近承で波及するが, helicotrema の 方间へは余り搪大姑ず $13.7 \mathrm{~mm}$ 附近をでな゙ある。

このように，刺激音の周波数加 1000 zps，2000 cps， $4000 \mathrm{cps}$ と增加するにつれて, Corti's organ における 病変部位も次第に基底膜上を basal end の方向に向つ て移動するが, 逆力间の helicotrema に间つては病変 部位は殆んど移動しない。

要するに，本実験成續を総括すれば，1000 cps 刺激群 のらち弱い刺激によつて最も強い恋化の現われる 部位 は, 基底膜上 basal end より 10.0 10.6mm 附近（第 2 回董上部)、であり，刺激が增大するにつれて，この部 位は basal end の方向に移動して $8.0 \sim 9.4 \mathrm{~mm}$ 附近 (第 2 回祘下部) に出現する. $2000 \mathrm{cps}$ 剌激群:では最る 強い病変は、これよりも basal end よりの7.0 7.8mm

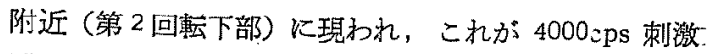
群では，さらに basal end にずれて 6.4〜 7.2mm 附近

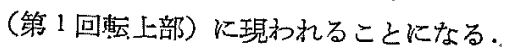

各振動数別に，音圧と瞅露時間を一定にして病変の強 さを観察すると，すべてが同一というのではなくて， 4000eps のそ水が 1000 执よび 2000 sps の病変上り。強. いといら結梁が表わ机ていた。たとえば，1000cps，120、 $\mathrm{d} b, 17$ 分の例では，有毛細胞は第 1 度の病変を示して いたのに対し，4000cps，120db，15 分の例では，実に第： 3 度病变といら高度の崩䫱像を示していた。このような 事垁は，ある一定の損傷をきたすに必要な刺激強度は各、 振動数によつてまらまちであると推定される根拠である. が，これは Gisselsson ${ }^{18)}$ の臨床成續と一致して括り， 彼は人耳を用いて 500，1000，2000 むよび 4000cps の各. 振動数について 音響曝露实験を行い, その結果, 1000 . 又は $2000 \mathrm{cps}$ より $4000 \mathrm{cps}$ がより效罙的に作用した と述ベた.

\section{V. 結語}

正常な聴器を有与ると考えられるモルそツ:を対象と し，1000，2000 括よび $4000 \mathrm{cps}$ の純音を刺激音として

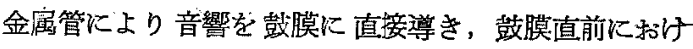
る音圧を $100 \sim 135 \mathrm{db}$ とし，2６0分間刺激した後に生

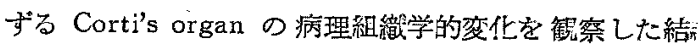
果,つぎのよらな結論をえた。

1. 㹉動数 $1000 \mathrm{cps}$ 刺激群について, 刺激の強さと刺

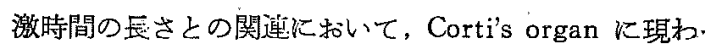
れる病変の可逆性と不可逆性を推察して雨者を分劃する。 Critical Intensity Line を設けた.

2. 同群におて, Corti's organ における最強い損 傷の起始部は basal end より 10.0 10.6mm の籍囲に 認められる。

3.同等に打いて，剌激を強めてその損傷部位の㹡が りかたを鹳察すると helicotrema の力问へは殆んど拡 がらず，専ら basal end の方向へ上り大きく桩がり， 最も強い損傷の中心部位は8.0〜9.4 $\mathrm{mm}$ に現われる一

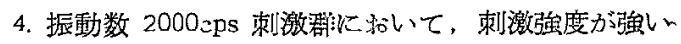
場合の損傷の中心部位は basal end より $7.0 \sim 7.8 \mathrm{~mm}$ の笻囲であり，1000zps 刺激群よりも basal end に近 すर<

5. 振動数 $4000 \mathrm{cps}$ 刺激群に扣いては, 損傷の中心部.

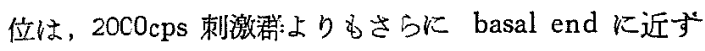
いて，6.4〜7.2mm の簛囲に出現する。 


\section{主 要 文 献}

1) Perlman H.B.: Acoustic trauma in man. Arch. Otolaryng. $34: 429,1941$.

2) Lurie M.H., Davis

H. \& Hawkins J.E.: Acoustic trauma of the organ of Corti in the guinea pig. Laryngoscope 65:375, 1949. 3) Békésy G.v.: The vibration of the cochlear partition in anatomical preparation and in models of the inner ear. J. Acous. Soc. Am., 21 : 233, 1949. 4) Davis H. et al: Acoustic trauma in the guinea pig. Wright Air Development Center Technical Report 53-58, 1953. 5) Ruedi L.: Diffrerent types and degrees of the acoustic trauma by experimental exposure of the human and animal ear to pure tones and noise. Annals Oto. Rhino. and Laryng., 63: 702, 1954. 6) Yoshii U.: Experimental Untersuchungen über die Schädigung des Gehör. organs durch Schalleinwirkung. Z. Ohrenheilk usw., .201, 1909. 7) Zuislocki J. \& Luescher E.: Adaptation of the ear to sound stimuli. J. Acous. Soc. Am. 21 : 135, 1949. 8) 山川强四郎：㙏器生体固定法 ，の技術，日耳荓全畫，2；430，1936.9）堀川基治：モ ルモットの Corti's organ $の$ graphic cochlear reconstruction 法; 日大医諗，19巻，8号，1960，揭載予定. 10) Werner C.F.: Protoplasmakugeln im Cortischen - Organ bei experimentelle Schallschädigung. Arch. . Ohren-usw. Heilk. u. Z. Halsusw. Heilk., 172: 221, 1558. 11) Lindsay J.R., Kobrak H. E Perlman H.B.: Relation of the stapedius reflex to hearing -sensation in man. Arch. Otolaryng., 25: 671, 1936.

12) Katsuki Y. $\mathfrak{G}^{2}$ Covell W.P.: The organ of Co- rti by phase contrast microscopy. Laryngoscope 62 : 1, 1953. 13) Eldredg D.H., Covell W.P. \& Davis H.: Recovery from acoustic trauma in the guinea. pig. Laryngoscope 67:66,1957. 14) 久保正婎, 志

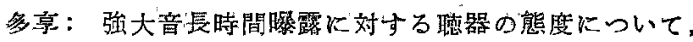
Audiology 2: 2,1959. 15) Spoendlin H.: Submikrotische Veranderungen am Cortischen Organ des meerschweinisches nach akustischer Belastung. Prakt. Oto. Rhino. und Laryng., 20: 197, 1958. 16) 曹島貢：蝸牛反応飞関する研究，日耳鼻，58；856，

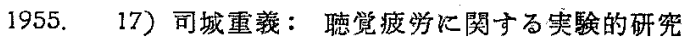
純音の短時間刺激による聴閾値の変動について, 日大医 萿, 18; 1023, 1959. 18) Gisselsson L.: Experimental investigation into the problem of humoral transmission in the cochlea. Acta Oto-Laryng., 82,

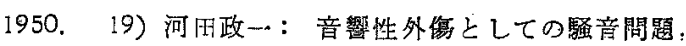
㞋耳鼻第 56 回学術撛演会宿題報告， 1955.

擱筆寸るに当り，御留篤なる御指導と御校閲 を賜つた恩師中村四郎教援に深甚の謝意安表し ます又，病理組織学的検查に当り，貴重なる 御示装之御援助を戴いた本学医学部病理学教室 馬場正郎教授に愿く感謝の意を表し亡す 本研究に対しては，昭和 33 年度交部省科学 研究費の補助をらけたので，附記して謝意を表 し屯要

本諭文の要旨は，第61回日本耳率咽陧科学 会総会に和いて発表した。

（原㼛到着=昭和 35.3.1 日） 


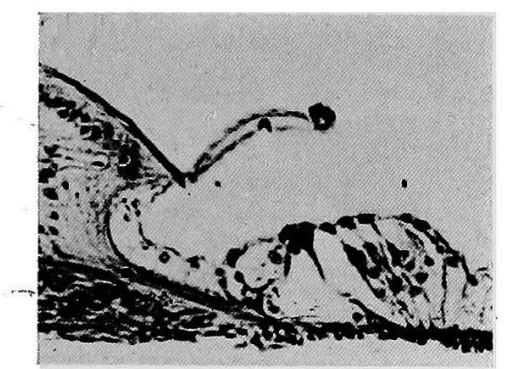

写真 1 ..病変第 1 度 $\mathbf{a}$ 有毛細胞の軽度腫脹

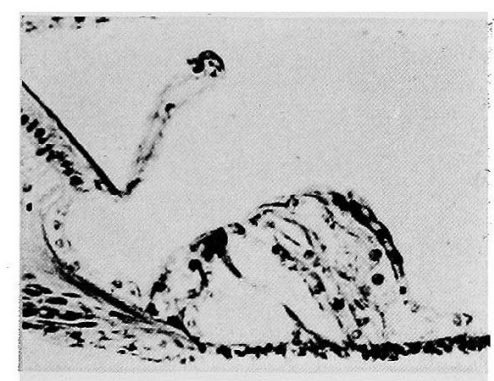

写真 2 病変第 1 度 b

有毛細胞や〉腫脹, 胞体間, トンネル腔に hyalin よ $\zeta$ exudate

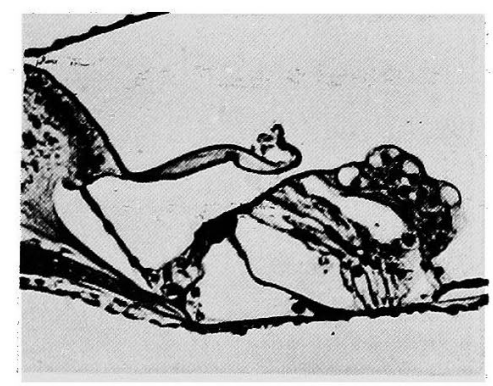

写真 3 病変第 2 度

有毛・支持細胞腫脹中等度, 支持細胞は基 底膜より䟝離し始める. meso. 細胞減少

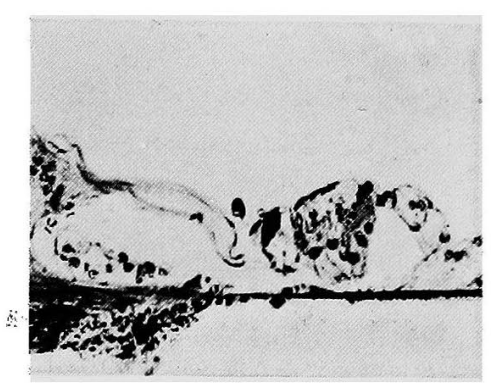

写真 4 病变第 3 度

有毛・支抹細胞崩壊著明, meso. 紐胞消失

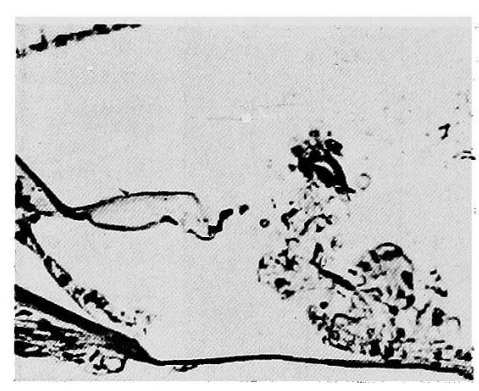

写可 5 病变第 3 度

有毛・支持細胞崩壤著明ない乙消失, meso. 細胞消失

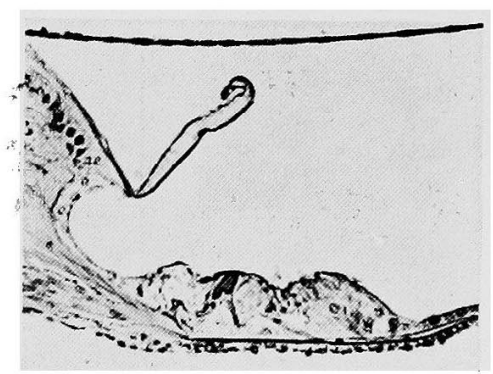

写真 $61 \mathrm{KC}, 120 \mathrm{db}, 60$ 分

Corti 器崩壊著明 (第 3 度病変) (10.5 mm 第 【回転上部) 
菊池論文付図（1）

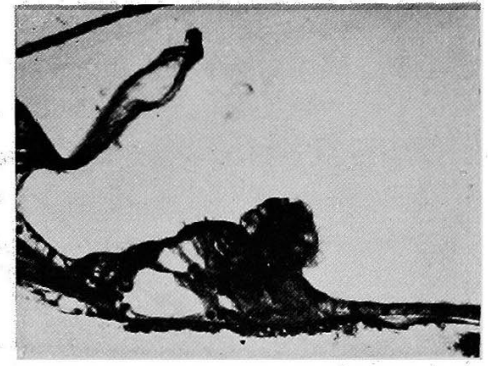

写真 $71 \mathrm{KC}, 135 \mathrm{db}, 30$ 分

基底膜に沿つて赤血球が配列 $(10.5 \mathrm{~mm}$ 第】回転上部)

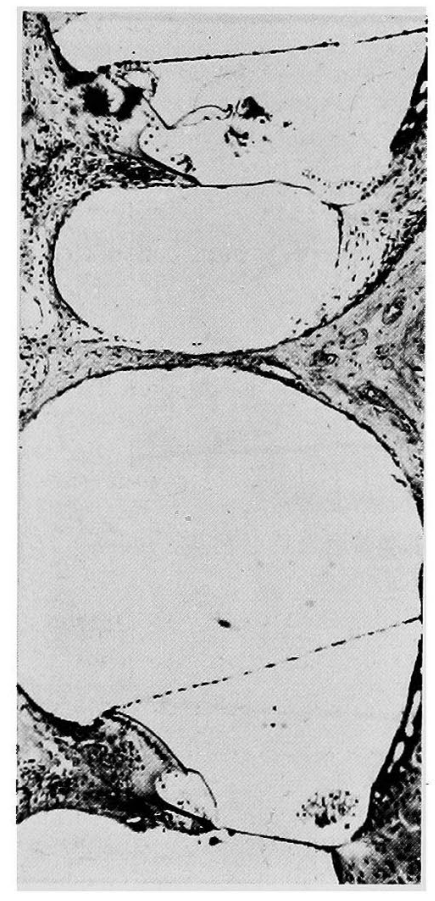

军真 8

$1 \mathrm{KC}, 135 \mathrm{db}, 60$ 分 Corti 器消失 (第 3 度病変)

上（第 II 回転上部） (10.9mm の部位) 下（第 I 回転上部） (6.5 mm の部位)

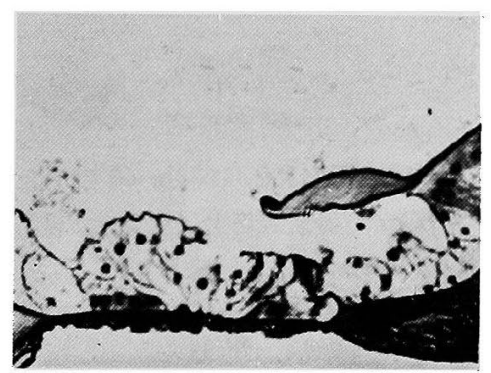

写真 $91 \mathrm{KC}, 135 \mathrm{db}, 60$ 分 Corti 器崩壊（第 3 度病変） $(3.0 \mathrm{~mm}$, 第 I 回転下部)

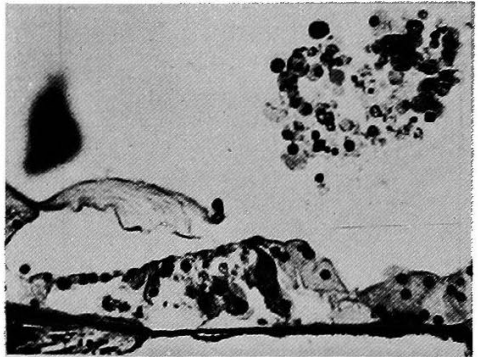

写真 $102 \mathrm{KC}, 120 \mathrm{db}, 60$ 分

Corti 器崩壞著明 (第 3 度病変)

$(6.5 \mathrm{~mm}$, 第 I 回転上部)

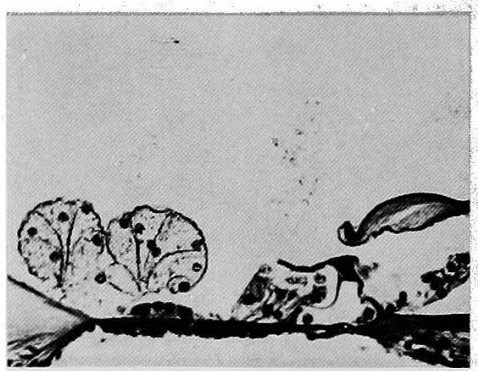

写真 $112 \mathrm{KC}, 135 \mathrm{db}, 2$ 時間

Corti 器崩壊 (第 3 度病变)

(2.2mm, 第 1 回転下部)
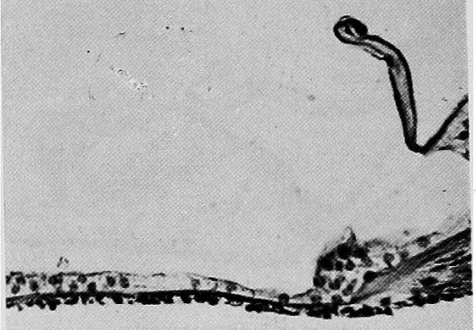

写真 $121 \mathrm{KC}, 135 \mathrm{db}, 3$ 時間，7 日連続 Corti 器消失 meso 細胞の減少は少ない 